\title{
Pengaruh Pertumbuhan Perusahaan Pada Nilai Perusahaan Dengan Pengungkapan CSR Sebagai Variabel Pemoderasi
}

\author{
Tebuana Agung Putra ${ }^{1}$ \\ Ketut Muliartha RM. ${ }^{2}$ \\ 1,2 Fakultas Ekonomi dan Bisnis Universitas Udayana (Unud), Bali, Indonesia \\ e-mail: tebuanaagung@gmail.com
}

\begin{abstract}
ABSTRAK
Penelitian ini memiliki tujuan untuk memperoleh bukti secara empiris mengenai pengaruh pertumbuhan perusahaan pada nilai perusahaan dengan pengungkapan Corporate Social Responsibility (CSR) sebagai variabel pemoderasi yang dilakukan di perusahaan manufaktur sektor consumer goods yang terdaftar di Bursa Efek Indonesia (BEI). Penelitian ini dilakukan pada perusahaan manufaktur sektor consumer goods yang terdaftar di BEI. Sampel ditentukan melalui metode non probability sampling dengan teknik purposive sampling. Jumlah pegamatan yang diperoleh dalam penelitian ini adalah sebanyak 60 data amatan selama periode pengamatan 2015-2017. Teknik analisis data yang digunakan adalah Moderated Regression Analysis (MRA). Hasil dari penelitian ini menunjukkan bahwa pertumbuhan perusahaan dan pengungkapan CSR tidak berpengaruh pada nilai perusahaan. Sedangkan pengungkpan CSR mampu memoderasi (memperkuat) pengaruh pertumbuhan perusahaan pada nilai perusahaan.

Kata kunci: pertumbuhan perusahaan, nilai perusahaan, pengungkapan CSR
\end{abstract}

\begin{abstract}
This study focussed to obtain empirical evidence of the effect of company growth on corporate value by disclosure of Corporate Social Responsibility (CSR) in manufacturing companies especially in the consumer goods sector that listed on the Indonesia Stock Exchange (IDX). This research was conducted at the consumer goods manufacturing company listed on the IDX. The sample is determined through non probability sampling method with purposive sampling technique. The number of observations obtained in this study is 60 data during the 2015-2017 observation period. The data analysis technique used is Moderated Regression Analysis (MRA). The results of this study indicate that company growth and CSR disclosure have no effect on firm value. Whereas the disclosure of CSR is able to moderate (strengthen) the influence of company growth on the value of the company. Keywords: Firm value, company growth, CSR disclosure
\end{abstract}

\section{PENDAHULUAN}

Globalisasi yang terjadi dalam bidang perekonomian Indonesia memberikan peluang baru kepada semua perusahaan. Indonesia yang merupakan bagian anggota ASEAN juga terkena dampak globalisasi sehingga mempunyai tantangan baru dalam menghadapi suatu pasar yang semakin kompetitif. Untuk mampu 
bersaing perusahaan memerlukan modal tambahan untuk melakukan kegiatan operasional dan investasinya. Hal ini mendorong perusahaan untuk menawarkan saham ke publik (go public).

Perusahaan yang sudah go public akan memiliki suatu tujuan utama baru, yaitu meningkatkan kemakmuran pemegang saham yang dilakukan dengan cara memaksimalkan nilai perusahaaan (Rasyid, 2015). Ketika sudah go public maka nilai dari suatu perusahaan dapat diartikan sebagai persepsi yang dimiliki oleh seorang investor pada perusahaan itu. Investor dapat menggunakan nilai perusahaan sebagai suatu dasar untuk melihat cerminan kinerja perusahaan di masa yang akan datang. Seorang investor akan menilai perusahaan yang baik adalah perusahaan dengan sumber daya yang melimpah. Perusahaan dengan nilai perusahan yang tinggi adalah perusahaan yang memiliki posisi keuangan yang baik.

Nilai perusahaan adalah persepsi investor terkait tingkat keberhasilan perusahaan untuk mensejahterakan para pemegang saham. Harmono (2009:233) menyatakan bahwa nilai perusahaan adalah kinerja perusahaan yang dicerminkan oleh harga saham yang dibentuk oleh permintaan dan penawaran pasar modal yang merefleksikan penilaian masyarakat terhadap kinerja perusahaan. Investor bisa menggunakan berbagai cara dalam menilai suatu perusahaan. Beberapa diantaranya adalah dengan menggunakan metode Price Earning Ratio (PER), Price to Book Value (PBV), dan Tobin's Q. 
Tabel 1.

Nilai Perusahaan Sektor Consumer Goods Periode 2015-2017 (Perhitungan Berdasarkan Rumus Tobin's Q)

\begin{tabular}{|c|c|c|c|c|}
\hline \multicolumn{5}{|c|}{ Nilai Perusahaan } \\
\hline \multirow{2}{*}{ No } & \multirow{2}{*}{ Kode Perusahaan } & \multicolumn{3}{|c|}{ Tahun } \\
\hline & & 2015 & 2016 & 2017 \\
\hline 1 & ADES & 1,4139 & 1,2678 & 1,1179 \\
\hline 2 & AISA & 0,9920 & 1,2157 & 0,7853 \\
\hline 3 & ALTO & 1,1724 & 1,2065 & 1,3883 \\
\hline 4 & CEKA & 0,8396 & 0,9406 & 0,9027 \\
\hline 5 & DLTA & 4,1915 & 3,4970 & 2,8872 \\
\hline 6 & DVLA & 1,3467 & 1,5739 & 1,6526 \\
\hline 7 & GGRM & 2,0679 & 2,3246 & 2,7833 \\
\hline 8 & HMSP & 11,6638 & 10,6763 & 12,9624 \\
\hline 9 & ICBP & 3,3413 & 3,8199 & 3,6397 \\
\hline 10 & INAF & 0,9530 & 11,1456 & 12,6073 \\
\hline 11 & INDF & 1,0252 & 1,3121 & 1,2296 \\
\hline 12 & KAEF & 1,9177 & 3,8188 & 3,0379 \\
\hline 13 & KLBF & 4,7190 & 4,8455 & 4,9314 \\
\hline 14 & LMPI & 0,6378 & 0,6643 & 0,7510 \\
\hline 15 & МBTO & 0,5617 & 0,6578 & 0,6563 \\
\hline 16 & MERK & 4,9923 & 5,7570 & 4,7692 \\
\hline 17 & MLBI & 9,3105 & 11,5603 & 12,3553 \\
\hline 18 & MYOR & 2,9469 & 3,3614 & 3,5349 \\
\hline 19 & PSDN & 0,7604 & 0,8400 & 1,1001 \\
\hline 20 & RMBA & 1,5458 & 1,6070 & 1,3485 \\
\hline 21 & ROTI & 2,9268 & 3,2798 & 2,1114 \\
\hline 22 & SIDO & 3,0213 & 2,6877 & 2,6716 \\
\hline 23 & SKBM & 1,9992 & 1,2306 & 1,1299 \\
\hline 24 & TCID & 1,7698 & 1,3342 & 1,7370 \\
\hline 25 & TSPC & 1,5629 & 1,6422 & 1,4059 \\
\hline 26 & ULTJ & 3,4286 & 3,2907 & 3,0731 \\
\hline 27 & UNVR & 18,6404 & 18,3979 & 23,2858 \\
\hline 28 & WIIM & 0,9696 & 0,9504 & 0,6612 \\
\hline
\end{tabular}

Tabel 1 menunjukkan nilai perusahaan-perusahaan sektor consumer goods yang terdaftar di BEI selama periode 2015-2017 dengan menggunakan rumus Tobin's Q. Melalui tabel 1 dapat dilihat bahwa terjadi kenaikan dan penurunan 
nilai perusahaan selama periode 2015-2017. Kenaikan dan penurunan ini bisa disebabkan oleh faktor-faktor tertentu. Gustian (2017) menyatakan bahwa naik turunnya nilai perusahaan dapat dijelaskan oleh beberapa faktor, yaitu pertumbuhan perusahaan, keputusan investasi, dan keputusan pendanaan. Dhani (2017) menyatakan bahwa nilai perusahaan dapat dijelaskan oleh pertumbuhan perusahaan, struktur modal, dan profitabilitas. Suwardika (2017) menyatakan bahwa nilai dari suatu perusahaan dapat dijelaskan oleh beberapa faktor, yaitu leverage, ukuran perusahaan, pertumbuhan perusahaan, dan profitabilitas.

Berdasarkan beberapa penelitian terdahulu, ada banyak faktor yang mampu menjelaskan naik turunnya nilai dari suatu perusahaan, namun ada satu faktor yang sama dan terbukti secara empiris yang berdasarkan penelitian terdahulu mampu menjelaskan naik turunnya nilai perusahaan yaitu pertumbuhan perusahaan. Kusumajaya (2011) berpendapat pertumbuhan perusahaan ialah jumlah naik atau turun total aset yang dimiliki perusahaan. Aset suatu perusahaan memiliki tujuan untuk digunakan pada kegiatan operasional perusahaan, semakin meningkatnya aktiva yang dimiliki perusahaan dapat meningkatkan hasil dari kegiatan operasionalnya sehingga memberikan sinyal positif kepada investor. Teori sinyal menyatakan bahwa jika sinyal yang diberikan oleh perusahaan ditangkap positif oleh investor, maka mereka akan tertarik untuk membeli saham perusahaan tersebut. Saat permintaan terhadap suatu saham meningkat, maka harga dari saham tersebut akan naik dan akan berdampak pada peningkatan nilai suatu perusahaan. 
Menurut Syardiana (2015), pertumbuhan dari suatu perusahaan akan menghasilkan tingkat pengembalian (return) yang semakin tinggi karena pertumbuhan dari suatu perusahaan memiliki aspek yang menguntungkan bagi investor. Penelitian terdahulu yang dilakukan untuk mengetahui hubungan antara pertumbuhan dengan nilai perusahaan oleh Dhani (2017) menunjukkan bahwa pertumbuhan perusahaan berpengaruh positif pada nilai perusahaan. Hasil yang serupa juga didapatkan dari penelitian yang telah dilakukan oleh Gustian (2017) dan Suastini (2016), namun hasil berbeda didapat dari penelitan terdahulu dengan variabel yang sama oleh beberapa peneliti. Suwardika (2017) menyatakan bahwa pertumbuhan perusahaan mempunyai pengaruh yang signifikan dengan arah negatif pada nilai perusahaan. Hasil yang serupa juga didapatkan dari penelitian yang telah dilakukan oleh Kesuma (2009) dan Hestinoviana, dkk (2013).

Penelitian terdahulu yang telah dilakukan oleh beberapa peneliti memperoleh hasil yang tidak konsisten. Ini mungkin terjadi dikarenakan ada faktor lain yang turut serta memengaruhi hubungan antara pertumbuhan perusahaan dengan nilai perusahaan. Pengambilan keputusan perekonomian yang hanya didasarkan dengan melihat nilai perusahaan dengan merefleksikan kondisi keuangan suatu perusahaan saja saat ini sudah tidak relevan lagi (Wijaya, 2015). Untuk mengatasi hal ini, investor membutuhkan suatu sarana yang memberikan informasi mengenai kegiatan tanggung jawab perusahaan yang didasari pada konsep triple bottom lines yang mencakup aspek sosial, lingkungan dan keuangan.

Menurut teori sinyal, pertumbuhan perusahaan hanya akan memberikan sinyal positif berupa keunggulan finansial (keuangan) yang dimiliki oleh suatu 
perusahaan, namun dari segi sosial dan lingkungan, informasi yang mampu memberikan sinyal positif bagi investor adalah informasi terkait pengungkapan Corporate Social Responsibility (CSR). World Business Council in Sustainable Development (WBCSD) menyatakan bahwa CSR merupakan komitmen dari suatu perusahaan untuk berperilaku etis serta berkontribusi dalam pembangunan ekonomi untuk meningkatkan kualitas hidup karyawan, komunitas lokal dan masyarakat. CSR sebagai komitmen perusahaan ditujukan untuk meminimalisir efek yang merugikan dan memaksimalkan efek yang menguntungkan secara jangka panjang terhadap masyarakat sebagai akibat dari kegiatan perusahaan (Adewale dan Sarah, 2012). Kegiatan CSR harus mengikut sertakan karakteristik sosial atau fitur dalam produk dalam proses manufaktur, misalnya menggunakan teknologi ramah lingkungan dalam proses produksi (McWilliams \& Siegel, 2001). CSR merupakan dilema bagi manajemen perusahaan. Hal ini disebabkan oleh pandangan aktivitas CSR dapat dilihat dari berbagai sudut pandang. Di satu sisi pandang CSR merupakan suatu pengorbanan karena untuk melakukan aktivitas CSR diperlukan biaya dan hasil yang didapatkan dari aktivitas CSR tidak bisa diukur menggunakan angka atau nilai nominal.

Menurut teori stakeholder, perusahaan dalam menjalankan aktivitasnya harus memperhatikan kepentingan semua pihak yang terlibat. Roberts (1992) mendefinisikan stakeholder seperti sebuah kelompok atau individual yang dapat memberi dampak atau terkena dampak oleh hasil tujuan perusahaan. Hubungan perusahaan dengan stakeholder, klien, masyarakat pada umumnya, dan dengan pemegang saham adalah bagian dari cakupan CSR (Crisóstomo, Freire, \& 
Vasconcellos, 2011). Berdasarkan pelaksanaan aktivitas CSR tersebut maka hubungan antara perusahaan dan stakeholder akan terbentuk dan mendapatkan respon positif di dalam menjalankan kegiatan operasionalnya. Pada saat ini, banyak investor menggunakan strategi investasi yang secara eksplisit mempertimbangkan kinerja corporate social responsibility selain ukuran finansial (Elliott, Jackson, Peecher, \& White, 2014). CSR tidak hanya merupakan suatu kewajiban yang harus dilaksanakan, CSR sekarang dilihat sebagai bagian integral dari strategi perusahaan (Choi, Kwak, \& Choe, 2010). Manajemen mengungkapkan informasi corporate social responsibility bertujuan untuk mendapat dukungan dari stakeholder (Gray, Owen, \& Adams, 1996). CSR dapat menjadi sumber inovasi, keunggulan kompetitif, dan penciptaan nilai bagi perusahaan (Husted \& Allen, 2007). Cheung et. al (2010) menyatakan bahwa penerapan CSR di Asia merupakan hal yang penting dan akan semakin menjadi sorotan di masa depan. Transparansi informasi merupakan hal yang sangat penting untuk menjaga keberlangusngan perusahaan (Jo \& Harjoto, 2011).

Aktivitas CSR yang dilakukan perusahaan kemungkinan akan memperkuat pengaruh pertumbuhan perusahaan pada nilai perusahaan. Ini terjadi karena dengan mengungkapkan CSR semakin banyak, biaya operasi suatu perusahaan akan menurun sehingga mampu meningkatkan dana yang tersedia bagi suatu perusahaan untuk bertumbuh. Dengan penerapan CSR, perusahaan biaya yang dikeluarkan untuk pemasaran produk akan berkurang dan tergantikan oleh biaya CSR. Walaupun biaya CSR awalnya merupakan biaya yang tidak berkontribusi 
dalam operasional perusahaan, namun kegiatan CSR nantinya akan berpengaruh terhadap kegiatan promosi sehingga meningkatkan penjualan perusahaan.

Menurut penelitian yang dilakukan oleh Cheung et al. (2010) penerapan CSR di Asia merupakan hal yang penting dan akan semakin menjadi sorotan di masa depan. Dewasa ini manajemen tidak bisa lagi hanya mengutamakan kepentingan pemegang saham. Bird et al. (2007) menyatakan bahwa manajemen dapat mempertimbangkan kepentingan dari beragam pemangku kepentingan tanpa secara signifikan mengorbankan kekayaan pemegang saham perusahaan. Penelitian yang telah dilakukan oleh Rustiarini (2010) menyatakan bahwa perusahaan akan mengungkapkan suatu informasi jika informasi tersebut dapat meningkatkan nilai perusahaan. Hasil penelitian yang dilakukan oleh Latupono (2015) serta Handriyani (2013) menemukan bahwa pengungkapan CSR berpengaruh positif pada nilai perusahaan.

Berdasarkan latar belakang yang sudah diuraikan, penelitian ini didasari oleh fenomena naik turunnya nilai perusahaan yang dapat dijelaskan oleh pertumbuhan perusahaan, namun berdasarkan penelitian terdahulu, terdapat ketidakkonsistenan hasil yang terjadi pada pengaruh pertumbuhan perusahaan pada nilai perusahaan. Hal ini kemungkinan disebabkan oleh adanya faktor lain yang mempengaruhi hubungan antara pertumbuhan perusahaan dengan nilai perusahaan. Berdasarkan konsep triple bottom lines, maka pengungkapan CSR diangkat sebagai variabel pemoderasi yang diduga dapat memperkuat pengaruh pertumbuhan perusahaan pada nilai perusahaan. Selain itu, peran pengungkapan CSR sebagai pemoderasi juga diteliti lebih lanjut apakah dia pure moderator, 
quasi moderator, homologizer, atau non moderator dengan cara selain mencari pengaruh pengungkapan CSR sebagai pemoderasi, pengaruh langsung pengungkapan CSR pada nilai perusahaan juga diteliti untuk menkonfirmasi tipe pemoderasinya.

Menurut teori sinyal, semakin tinggi pertumbuhan yang dialami oleh suatu perusahaan maka akan memancarkan sinyal positif kepada investor. Pertumbuhan dari suatu perusahaan dapat dicerminkan dari pertumbuhan aset akan memberikan sinyal bahwa perusahaan mampu mengelola sumberdaya untuk mengahasilkan keuntungan. Kinerja yang baik akan mengakibatkan naiknya permintaan investor untuk membeli saham perusahaan dan akhirnya meningkatkan nilai perusahaan.

Penelitian terdahulu yang telah dilakukan oleh Dhani (2017), Gustian (2017), dan Suastini (2016) mendukung konsep dari teori sinyal yang mengemukakan bahwa bahwa pertumbuhan perusahaan merupakan suatu aspek positif yang berdampak pada peningkatan nilai perusahaan. Dhani (2017) menyatakan bahwa perusahaan yang memiliki pertumbuhan aset yang tinggi menandakan perusahaan mampu mengelola sumberdaya untuk mengahasilkan laba. Gustian (2017) mengemukakan bahwa jika dilihat dari sudut pandang investor, perusahaan yang memiliki pertumbuhan yang baik akan menghasilkan tingkat pengembalian (rate of return) yang baik dari investasi yang dilakukannya. Suastini (2016) menyatakan bahwa pertumbuhan perusahaan merupakan suatu aspek positif dan memiliki pengaruh pada peningkatan nilai perusahaan.

Perusahaan dengan tingkat pertumbuhan yang tinggi menandakan bahwa kemampuan operasional perusahaan dalam mengelola sumber daya yang ada 
untuk memperoleh keuntungan tinggi. Informasi pertumbuhan perusahaan yang ditandai dengan peningkatan asetnya akan memberikan sinyal positif bagi investor. Dengan begitu investor akan tertarik untuk membeli saham yang artinya meningkatkan permintaan dari saham perusahaan tersebut. Dengan naiknya permintaan, maka harga saham akan naik dan akhirnya menyebabkan nilai perusahaan meningkat. Berdasarkan uraian tersebut maka hipotesis yang dapat dirumuskan adalah.

$\mathrm{H}_{1}$ : Pertumbuhan perusahaan berpengaruh positif pada nilai perusahaan

Teori stakeholder mengungkapkan bahwa perusahaan bukanlah entitas yang hanya beroperasi untuk kepentingannya sendiri namun harus memberikan manfaat bagi stakeholder. Hal ini akan berdampak pada semakin meningkatnya citra perusahaan di mata masyarakat dan investor karena perusahaan tidak hanya memperhatikan kepentingan para shareholder saja melainkan turut memperhatikan kepentingan para stakeholder. Dengan mengungkapkan semakin banyak aktivitas CSR maka akan memberikan sinyal positif pada investor terkait dengan tingkat sustainibilitas perusahaan yang semakin baik.

Latupono (2015) mengemukakan bahwa nilai dari suatu perusahaan akan sustainable apabila perusahaan memperhatikan aspek ekonomi, lingkungan hidup dan sosial dengan menerapkan CSR. Hal ini sejalan dengan penelitian Handriyani (2013) yang menemukan bahwa semakin tinggi tingkat pengungkapan CSR yang dilakukan perusahaan maka dapat meningkatkan nilai perusahaan. Penelitian oleh Nahda (2011) mengungkapkan bahwa perusahaan yang mengungkapkan CSR akan memiliki citra positif di masyarakat karena selain memperhatikan 
kepentingan para shareholder, perusahaan juga mempertimbangkan kepentingan para stakeholder sehingga keberadaan perusahaan bisa bertahan dan berdampak pada peningkatan nilai perusahaan. Berdasarkan uraian tersebut maka hipotesis yang dapat dirumuskan adalah.

$\mathrm{H}_{2}$ : Pengungkapan CSR berpengaruh positif pada nilai perusahaan

Menurut teori sinyal, pertumbuhan perusahaan akan akan memberikan sinyal positif pada investor. Pertumbuhan perusahaan yang semakin tinggi menandakan kemampuan perusahaan dalam menjalankan kegiatan operasionalnya semakin baik karena mampu menambah aset yang sudah ada, namun informasi pertumbuhan perusahaan tidak mampu memberikan sinyal terkait sustainabilitas perusahaan. Teori sinyal menyatakan bahwa pengungkapan CSR mampu memberikan sinyal positif terkait sustainabilitas perusahaan. Hal ini karena menurut teori stakeholder dengan mengungkapkan CSR semakin banyak, maka perusahaan akan memperoleh citra. Citra yang diperoleh oleh suatu perusahaan yang akan memberikan sinyal bagi investor terkait sustainibilitas perusahaan.

Perusahaan yang memiliki tingkat pertumbuhan tinggi dan disertai pengungkapan CSR yang semakin banyak akan memberikan sinyal positif yang lebih tinggi dibandingkan perusahaan yang memiliki tingkat pertumbuhan tinggi namun pengungkapan CSR yang sedikit. Berdasarkan uraian tersebut maka hipotesis yang dapat dirumuskan adalah:

$\mathrm{H}_{3}$ : Pengungkapan CSR memperkuat pengaruh pertumbuhan perusahaan pada nilai perusahaan 


\section{METODE PENELITIAN}

Populasi yang digunakan dalam penelitian ini adalah seluruh perusahaan manufaktur sektor consumer goods yang terdaftar di Bursa Efek Indonesia periode 2015-2017. Hal ini didasarkan pada Tabel 2, sektor yang memiliki rata-rata indeks harga saham tertinggi, yaitu sebesar Rp. 2416,861 dan pergerakannya cenderung naik selama tiga tahun terakhir adalah sektor consumer goods. Hal ini mengindikasikan bahwa sektor consumer goods memiliki gambaran kinerja yang baik selama periode 2015-2017. Dengan tingginya pergerakan naik dari indeks harga saham sektor consumer goods kemungkinan besar memberikan peluang prospek yang baik di masa depan. Jangka waktu tiga tahun bertujuan untuk mendapatkan data terbaru dan harapannya memperoleh hasil yang baik.

Tabel 2.

Indeks Harga Saham Sektoral Periode 2015-2017

\begin{tabular}{lcccc}
\hline \multirow{2}{*}{ Sector } & \multicolumn{4}{c}{ Harga Saham (Rp) } \\
\cline { 2 - 5 } & 2015 & 2016 & 2017 & Rata-Rata \\
\cline { 2 - 5 } Agriculture & 1719,262 & 1864,249 & 1616,307 & 1733,273 \\
Mining & 811,072 & 1384,706 & 1593,999 & 1263,259 \\
Basic Industry \& Chemicals & 407,839 & 538,189 & 689,219 & 545,082 \\
Miscellaneous Industry & 1057,275 & 1370,628 & 1381,177 & 1269,693 \\
Consumer Goods Industry & 2064,91 & 2324,281 & 2861,391 & 2416,861 \\
Property, Realestate \& Building & 490,933 & 517,81 & 495,51 & 501,418 \\
Construction & 981,333 & 1055,587 & 1183,708 & 1073,543 \\
Infrastructure, Utilities and & 687,039 & 811,893 & 1140,837 & 879,923 \\
Transportation & 849,527 & 860,654 & 921,589 & 877,257 \\
Finance & & & & \\
Trade \& Service & & & & \\
\hline Sumber: Data diolah, 2018 & & & & \\
\end{tabular}

Tobin's Q mewakili sejumlah variabel yang penting dalam mengukur nilai suatu perusahaan, yaitu aktiva perusahaan, kecenderungan pasar prospek 
perusahaan, dan variabel aset tak berwujud, formulasinya adalah sebagai berikut (Chung et al., 2005):

$Q=\frac{M V E+D E B T}{T A}$

Keterangan:

$\mathrm{Q} \quad=$ Nilai Perusahaan

MVE = Nilai pasar ekuitas (jumlah saham beredar $\times$ closing price)

DEBT $=$ Total Kewajiban

TA $=$ Nilai buku total aset

Pengukuran pertumbuhan aset perusahaan dapat diukur menggunakan rasio Asset Growth (AG) yang dirumuskan sebagai berikut:

$A G=\frac{\text { Total Asset }_{t}-\text { Total Asset }_{t-1}}{\text { Total Asset }_{t-1}}$

Keterangan:

AG $\quad=$ Asset Growth

Total Assett $=$ Total Aset tahun berjalan

Total Assett-1 = Total Aset tahun sebelumnya

Pengukuran tanggung jawab sosial perusahaan dapat dilakukan dengan indeks pengungkapan tanggung jawab sosial perusahaan (indeks CSRDI). Formula perhitungan dapat dilakukan sebagai berikut (Bidhari, Salim, \& Aisjah, 2013):

$\operatorname{CSRDI}_{j}=\frac{\sum x_{i j}}{n_{j}}$

Keterangan:

CSRDI $_{\mathrm{j}}=$ Indeks CSR berdasarkan GRI G4, $0 \leq \mathrm{CSRDIj} \leq 1$.

$\sum X_{i j} \quad=\quad$ Jumlah pengungkapan yang dilakukan perusahaan

$\mathrm{n}_{\mathrm{j}} \quad=\quad$ Jumlah maksimal penilaian yaitu 91 (GRI G4).

Teknik analisis data dalam penelitian ini menggunakan uji Moderate Regression Analysis (MRA). Uji interaksi merupakan salah satu cara yang dapat 
digunakan untuk menguji apakah suatu variabel merupakan variabel moderating. Uji interaksi antar variabel disebut dengan Moderated Regression Analysis (MRA). MRA dalam penelitian ini digunakan untuk menguji pengaruh pengungkapan CSR dalam memoderasi hubungan antara pengaruh pertumbuhan perusahaan pada nilai perusahaan. Persamaan MRA adalah sebagai berikut.

$Y=\alpha+\beta_{1} X_{1}+\beta_{2} X_{2}+\beta_{3} X_{1} X_{2}+\epsilon$

Keterangan:

Y : Nilai Perusahaan

a : Konstanta

$\beta_{1-3} \quad$ : Koefisien Regresi

$\mathrm{X}_{1} \quad$ : Pertumbuhan Perusahaan

$\mathrm{X}_{2} \quad$ : Pengungkapan CSR

$\mathrm{X}_{1} \mathrm{X}_{2}$ : Interaksi antara pertumbuhan perusahaan dengan CSR

$\epsilon \quad$ : Error

\section{HASIL DAN PEMBAHASAN}

Hasil statistik deskriptif dapat dilihat pada Tabel 3 sebagai berikut.

Tabel 3.

Statistik Deskriptif Penelitian

\begin{tabular}{lccccc}
\hline Variable & $\mathrm{N}$ & Minimum & Maximum & Mean & Std. Deviation \\
\hline $\mathrm{Y}$ & 60 & 0,5617 & 3,8188 & 1,6865 & 0,9059 \\
$\mathrm{X} 1$ & 60 & $-0,1459$ & 0,6203 & 0,1057 & 0,1514 \\
$\mathrm{X} 2$ & 60 & 0,0110 & 0,5055 & 0,1882 & 0,1236 \\
\hline
\end{tabular}

Sumber: Data diolah, 2018

Berdasarkan hasil uji statistik deskriptif pada tabel 3, dapat dijelaskan variabel nilai perusahaan (Y) memiliki nilai minimum sebesar 0,5617 dengan nilai maksimum sebesar 3,8188 dan nilai rata-rata sebesar 1,6865. Nilai minimum sebesar 0,5617 dimiliki oleh PT. Martina Berto Tbk pada tahun 2015 yang berarti perusahaan tersebut dinilai lebih rendah dari nilai bukunya oleh pasar sehingga hanya bernilai 0,5617 atau $56,17 \%$ dari nilai buku. Nilai maksimum sebesar 3,8188 dimiliki oleh PT. Kimia Farma Tbk pada tahun 2016 yang berarti 
perusahaan tersebut dinilai lebih tinggi oleh pasar dari nilai bukunya sebesar 3,8188 atau $381,88 \%$ dari nilai buku. Nilai rata-rata (mean) sebesar 1,6865 yang berarti rata-rata perusahaan sektor consumer goods dinilai lebih tinggi dari nilai bukunya oleh pasar yaitu sebesar 1,6865 atau 168,65\% dari nilai buku. Standar deviasi dari nilai perusahaan sebesar 0,9059 yang berarti data nilai perusahaan cenderung homogen (mendekati nol) dengan sebaran data normal cenderung ke kiri seperti pada gambar 1 berikut.

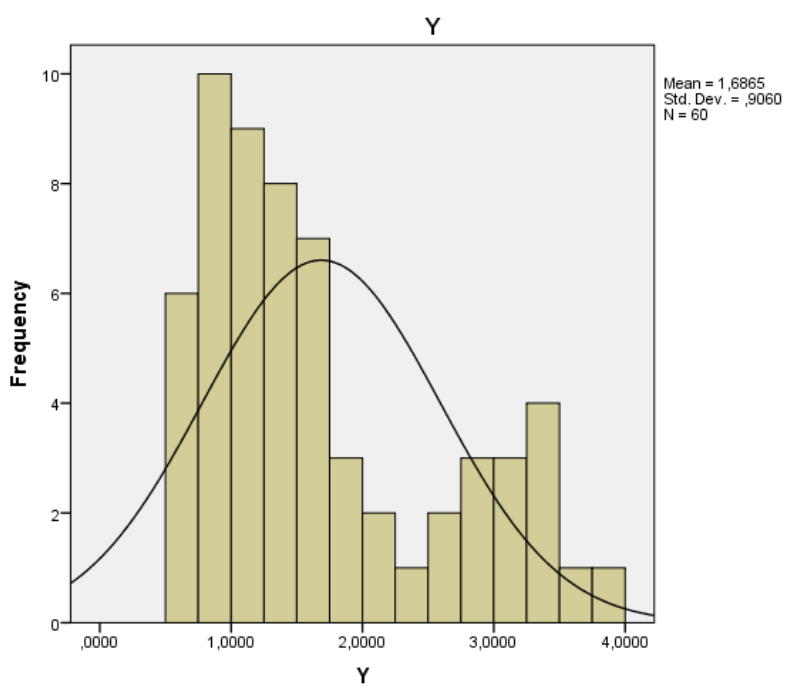

Gambar 1. Sebaran Data Nilai Perusahaan Sumber: Data diolah, 2018

Variabel pertumbuhan perusahaan $\left(\mathrm{X}_{1}\right)$ memiliki nilai minimum sebesar 0,1459 dengan nilai maksimum sebesar 0,6203 dan nilai rata-rata sebesar 0,1057. Nilai minimum sebesar $-0,1459$ dimiliki oleh PT. Sekar Bumi Tbk pada tahun 2015 yang berarti perusahaan tersebut mengalami penurunan total aset sebesar 0,1459 atau $14,59 \%$ dengan tahun dasar 2014. Nilai maksimum sebesar 0,6203 dimiliki oleh PT. Sekar Bumi Tbk juga pada tahun 2017 yang berarti perusahaan tersebut mengalami kenaikan total aset sebesar 0,6203 atau 62,03\% dengan tahun 
dasar 2016. Nilai rata-rata (mean) sebesar 0,1057 yang berarti rata-rata perusahaan sektor consumer goods mengalami peningkatan aset sebesar 0,1057 atau 10,57\% selama periode 2015-2017. Standar deviasi dari pertumbuhan perusahaan sebesar 0,1514 yang berarti data nilai perusahaan cenderung homogen (mendekati nol) dengan sebaran data normal cenderung ke kiri seperti pada gambar 2 berikut.

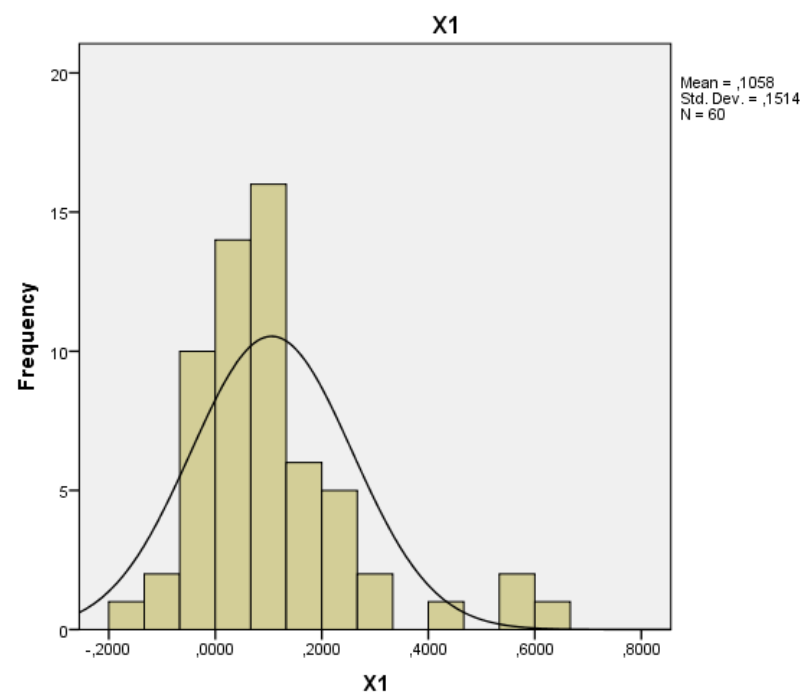

Gambar 2. Sebaran Data Pertumbuhan Perusahaan

Sumber: Data diolah, 2018

Variabel pengungkapan CSR $\left(\mathrm{X}_{2}\right)$ memiliki nilai minimum sebesar 0,0110 dengan nilai maksimum sebesar 0,5055 dan nilai rata-rata sebesar 0,1882 . Nilai minimum sebesar 0,0110 dimiliki oleh PT. Wilmar Cahya Indonesia Tbk pada tahun 2015 yang berarti perusahaan tersebut hanya mengungkapkan CSR sebanyak 0,0110 atau 1,1\% dari 91 jenis pengungkapan. Nilai maksimum sebesar 0,5055 dimiliki oleh PT. Indofood Sukses Makmur Tbk pada tahun 2016 dan 2017 yang berarti perusahaan tersebut mengungkapkan CSR sebanyak 0,5055 atau 50,55\% dari 91 jenis pengungkapan. Nilai rata-rata (mean) sebesar 0,1882 
yang berarti rata-rata perusahaan sektor consumer goods mengungkapkan CSR sebanyak 0,1882 atau $18,82 \%$ dari 91 jenis pengungkapan. Standar deviasi dari pengungkapan CSR sebesar 0,1236 yang berarti data nilai perusahaan cenderung homogen (mendekati nol) dengan sebaran data normal cenderung ke kiri seperti pada gambar 3 berikut.

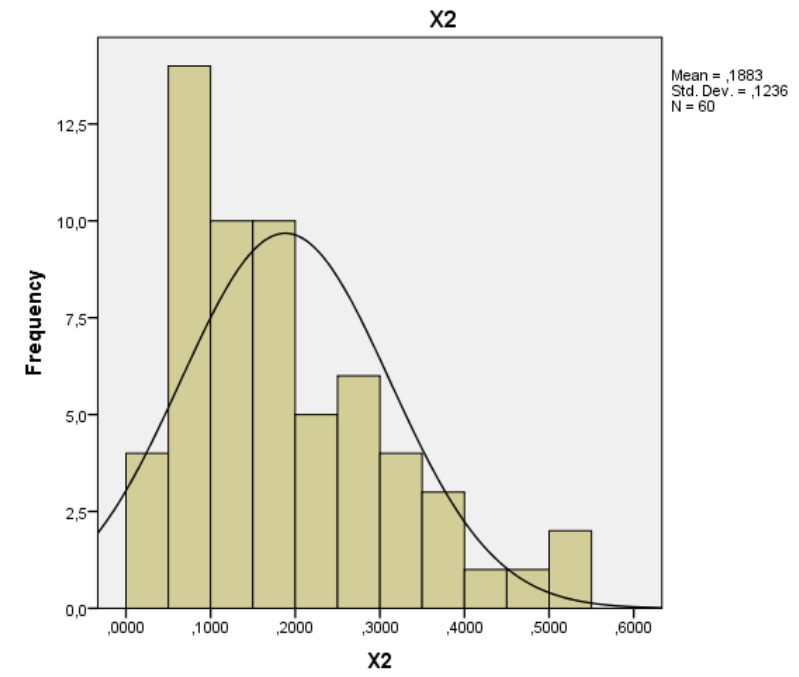

Gambar 3. Sebaran Data Pengungkapan CSR

Sumber: Data diolah, 2018

Moderated Regressiom Analysis (MRA) merupakan uji yang dilakukan untuk mengetahui apakah Corporate Social Responsibility (CSR) mampu memengaruhi hubungan pertumbuhan perusahaan pada nilai perusahaan. Hasil pengujian disajikan pada Tabel 4 berikut ini.

Tabel 4.

Hasil Uji Moderated Regression Analysis

\begin{tabular}{lcccc}
\hline Variabel & \multicolumn{2}{c}{$\begin{array}{c}\text { Cnstandardized } \\
\text { Coefficient }\end{array}$} & $\begin{array}{c}\text { Standardized } \\
\text { Coefficient }\end{array}$ & Sig. \\
& $\mathrm{B}$ & Std. Error & Beta & \\
\hline (Constant) & 1,405 & 0,215 & & 0,000 \\
$\mathrm{X} 1$ & $-1,569$ & 1,337 & $-0,262$ & 0,246 \\
$\mathrm{X} 2$ & 0,465 & 0,908 & 0,063 & 0,611 \\
$\mathrm{X} 1 \_\mathrm{X} 2$ & 18,646 & 6,228 & 0,678 & 0,004 \\
\hline $\mathrm{R}^{2}$ & $:$ & 0,250 & & \\
F Sig. & $:$ & 0,001 & & \\
\hline
\end{tabular}

Sumber: Data diolah, 2018 
Adapun persamaan regresi yang dihasilkan dari dalam penelitian ini adalah:

$$
Y=1,405-1,569 X_{1}+0,465 X_{2}+18,646 X_{1} X_{2}+0,215
$$

Berdasarkan hasil dari uji MRA, terlihat nilai konstanta sebesar 1,405 mempunyai arti bahwa apabila nilai variabel independen yaitu pertumbuhan perusahaan dan pengungkapan CSR sama dengan nol, maka nilai perusahaan adalah sebesar 1,405 dengan asumsi variabel independen konstan. Berdasarkan tabel 4 terlihat bahwa p-value dari pertumbuhan perusahaan (X1) sebesar 0,246>0,05 (tidak signifikan), dan p-value dari pengungkapan CSR (X2) sebesar 0,611>0,05 (tidak signifikan). Kedua variabel tersebut ternyata memperoleh hasil yang tidak signifikan, yang berarti naik turunnya variabel pertumbuhan maupun pengungkapan CSR tidak mampu menjelaskan variasi perubahan nilai perusahaan secara signifikan, namun pada variabel interaksi (X1_X2) memiliki p-value sebesar 0,004<0,05 (signifikan). Hal ini berarti pengungkapan CSR mampu memoderasi (memperkuat) pengaruh pertumbuhan perusahaan pada nilai perusahaan. Dilihat dari $p$-value pengaruh langsung pengungkapan CSR pada nilai perusahaan dengan $p$-value kemampuan pengungkapan CSR dalam memoderasi, maka dapat ditarik kesimpulan bahwa pengungkapan CSR merupakan pemoderasi tipe pure moderator. Variabel pengungkapan CSR dapat dikatakan pure moderator karena hasil uji interaksi antara variabel pengungkapan CSR dengan hubungan antara variabel pertumbuhan perusahaa pada variabel nilai perusahaan memperoleh hasil yang signifikan $(0,004<0,05)$ namun hubungan langsung antara variabel pengungkapan CSR dengan variabel nilai perusahaan tidak signifikan $(0,611>0,05)$. 
Koefisien determinasi yang digunakan pada analisis regresi moderasi adalah nilai $\mathrm{R}^{2}$. Hasil analisis yang terlihat pada Tabel 4, menunjukkan nilai $\mathrm{R}^{2}$ dari model persamaan memiliki nilai sebesar 0,250 . Ini berarti $25 \%$ variasi nilai perusahaan dapat dijelaskan oleh variabel pertumbuhan perusahaan dan pengungkapan CSR, sedangkan $75 \%$ sisanya dijelaskan oleh faktor lain yang tidak diuji dalam model penelitian ini. Hasil analisis yang terlihat pada Tabel 4 menunjukkan nilai signifikansi $F$ sebesar $0,001<0,05$. Hasil ini menunjukkan bahwa variabel pertumbuhan perusahaan, pengungkapan CSR serta interaksinya berpengaruh pada nilai perusahaan. Berdasarkan hal tersebut maka dapat disimpulkan bahwa model penelitian ini layak untuk diteliti.

Berdasarkan Tabel 4 hasil uji statistik t menunjukkan bahwa pertumbuhan perusahaan memiliki t negatif sebesar -1,174 dengan nilai $p$-value sebesar 0,246> 0,05. Berdasarkan hasil uji tersebut tidak dapat membuktikan hipotesis pertama. Pertumbuhan perusahaan dalam penelitian ini menggunakan kenaikan atau penurunan total aset. Semakin tinggi kenaikan total aset belum tentu meningkatkan keinginan para investor untuk membeli saham perusahaan tersebut. Karena kenaikan dari total aset bisa dari berbagai macam faktor, baik keuntungan atau bisa bersasal dari peberbitan obligasi dan penerbitan saham baru. Sehingga masih belum pasti apakah dari kenaikan total aset berarti perusahaan mempu mengelola sumber daya yang ada untuk memperoleh laba sehingga menghasilkan kinerja yang baik. Hasil penelitian sejalan dengan penelitian yang dilakukan oleh Meidiawati (2016) serta penelitian yang dilakukan oleh Puspita (2011) yang 
menemukan hasil bahwa pertumbuhan perusahaan tidak berpengaruh pada nilai perusahaan.

Berdasarkan Tabel 4 hasil uji statistik t menunjukkan bahwa pertumbuhan perusahaan memiliki t positif sebesar 0,512 dengan nilai $p$-value sebesar $0,611>$ 0,05. Berdasarkan hasil uji tersebut tidak dapat membuktikan hipotesis kedua.Besar kecilnya luas pengungkapan CSR yang dilakukan oleh perusahaan, tidak dapat memengaruhi nilai perusahaan. Walaupun perusahaan mengungkapkan CSR dan mendapatkan citra di mata para stakeholder, Sulit untuk menentukan benefit perusahaan yang menerapkan CSR, karena tidak ada yang dapat menjamin bahwa bila perusahaan yang telah mengimplementasikan CSR dengan baik akan mendapat kepastian benefitnya. Penelitian ini sejalan dengan penelitian penelitian yang telah dilakukan oleh Bella (2017) dan Ramona (2017) yang menyatakan bahwa pengungkapan CSR tidak berpengaruh secara signifikan pada nilai perusahaan.

Berdasarkan Tabel 4 hasil uji statistik t menunjukkan bahwa interaksi pertumbuhan perusahaan dan pengungkapan CSR memiliki t positif sebesar 2,994 dengan nilai $p$-value sebesar $0,004<0,05$. Berdasarkan hasil uji tersebut dapat membuktikan hipotesis ketiga. Aktivitas CSR yang dilakukan perusahaan akan memperkuat pengaruh pertumbuhan perusahaan pada nilai perusahaan. Aktivitas CSR yang dilakukan perusahaan kemungkinan akan memperkuat pengaruh pertumbuhan perusahaan pada nilai perusahaan. Teori stakeholder menyatakan bahwa dengan mengungkapkan CSR semakin banyak, maka perusahaan akan memperoleh citra. Citra yang didapat oleh perusahaan dengan melakukan kegiatan 
CSR secara tidak langsung akan mempromosikan perusahaan dan dapat menurunkan biaya operasi untuk pemasaran produk. Dengan penurunan biaya operasi maka dana yang tersedia bagi suatu perusahaan untuk bertumbuh akan bertambah. Meningkatnya dana yang tersedia untuk perusahaan semakin bertumbuh akan semakin meningkatkan tingkat pertumbuhan perusahaan.

Menurut teori sinyal, pertumbuhan perusahaan akan akan memberikan sinyal positif pada investor. Pertumbuhan perusahaan yang semakin tinggi menandakan kemampuan perusahaan dalam menjalankan kegiatan operasionalnya semakin baik karena mampu menambah aset yang sudah ada, namun informasi pertumbuhan perusahaan tidak mampu memberikan sinyal terkait sustainabilitas perusahaan. Teori sinyal menyatakan bahwa pengungkapan CSR mampu memberikan sinyal positif terkait sustainabilitas perusahaan. Dengan demikian pengungkapan CSR memperkuat pengaruh pertumbuhan perusahaan karena selain memberikan sinyal terkait kemampuan operasionalnya yang baik, perusahaan juga memberikan jaminan terkait sustainabilitas perusahaan di masa depan dengan mengungkapkan CSR. Perusahaan yang memiliki tingkat pertumbuhan tinggi dan disertai pengungkapan CSR yang semakin banyak akan memberikan sinyal positif yang lebih tinggi dibandingkan perusahaan yang memiliki tingkat pertumbuhan tinggi namun pengungkapan CSR yang sedikit.

\section{SIMPULAN}

Berdasarkan hasil pengujian yang dilakukan hanya satu pengujian yang mendukung hipotesis, yaitu pengungkapan CSR memoderasi (memperkuat) 
pengaruh pertumbuhan perusahaan pada nilai perusahaan. Sedangkan dua pengujian tidak mendukung hipotesis, yaitu pertumbuhan perusahaan berpengaruh positif pada nilai perusahaan dan pengungkapan CSR berpengaruh positif pada nilai perusahaan. Berdasarkan ketiga pengujian yang telah dilakukan dapat disimpulkan bahwa pengungkapan CSR memperkuat pengaruh pertumbuhan perusahaan pada nilai perusahaan, sedangkan pertumbuhan perusahaan dan pengungkapan CSR tidak memiliki pengaruh pada nilai perusahaan secara langsung.

Berdasarkan simpulan penelitian disampaikan sebelumnya, terlihat bahwa Nilai $\mathrm{R}^{2}$ yang rendah yaitu sebesar $25 \%$ menunjukkan bahwa adanya keterbatasan variabel independen yang digunakan dalam menjelaskan variabel dependen (nilai perusahaan). Ada 75\% dari variasi nilai perusahaan dapat dijelaskan oleh variabelvariabel lain di luar model penelitian. Bagi peneliti selanjutnya diharapkan dapat meneliti variabel lain yang dapat menjelaskan naik turunnya nilai perusahaan seperti leverage (utang). Pemilihan pengukuran pertumbuhan perusahaan, dan pengungkapan CSR didasarkan pada kajian literatur penelitian sebelumnya sehingga pengukuran variabel nilai perusahaan masih terpaku hanya pada satu macam pengukuran saja. Bagi peneliti selanjutnya peru diketahui untuk mempertimbangkan metode pertumbuhan penjualan dalam menjelaskan pertumbuhan perusahaan dan menggunakan pengukuran ISO 26000 dalam menjelaskan pengungkapan CSR.

Bagi peneliti selanjutnya perlu diketahui bahwa hasil penelitian ini tidak dapat digeneralisasi untuk seluruh perusahaan yang terdaftar di Bursa Efek 
Indonesia, karena penelitian ini hanya menggunakan perusahaan manufaktur sektor consumer goods sebagai ruang lingkup penelitian. Penelitian ini hanya menggunakan periode tiga tahun. Diharapkan bagi penelitian selanjutnya untuk menghindari keterbatasan dalam penelitian ini pada penelitian selanjutnya, yaitu dengan menggunakan periode pengamatan yang berbeda serta menambah periode pengamatan sehingga dapat digunakan untuk memprediksi dan hasil penelitian selanjutnya semakin baik.

\section{REFERENSI}

Adewale, A. R., \& Sarah, R. N. (2012). The Impact of Corporate Social Responsibility on The Profitability of Listed Retailers: Indication from the Johannesburg Security Exchange (JSE). African Journal of Business Management, 6(4), 1694-1701. https://doi.org/10.5897/AJBM11.1527

Bella, G., \& Suaryana, I. G. N. A. (2017). Pengaruh IOS dan Pengungkapan CSR pada Nilai Perusahaan dengan Pertumbuhan Perusahaan sebagai Variabel Pemoderasi. E-Jurnal Akuntansi Universitas Udayana, 19(1), 508-535.

Bidhari, S. C., Salim, U., \& Aisjah, S. (2013). Effect of Corporate Social Responsibility Information Disclosure on Financial Performance and Firm Value in Banking Industry Listed at Indonesia Stock Exchange. European Journal of Business and Management, 5(18).

Bird, R., Hall, A. D., Momentè, F., \& Reggiani, F. (2007). What corporate social responsibility activities are valued by the market? Journal of Business Ethics, 76(2), 189-206. https://doi.org/10.1007/s10551-006-9268-1

Cheung, Y. L., Tan, W., Ahn, H. J., \& Zhang, Z. (2010). Does corporate social responsibility matter in Asian Emerging Markets? Journal of Business Ethics, 92(3), 401-413. https://doi.org/10.1007/s10551-009-0164-3

Choi, J.-S., Kwak, Y.-M., \& Choe, C. (2010). Corporate social responsibility and corporate financial performance: Evidence from Korea. Australian Journal of Management, 35(3), 291-311.

Chung, R., Firth, M., \& Kim, J. B. (2005). FCF agency costs, earnings management, and investor monitoring. Corporate Ownership and Control, 
2(4), 51-61. https://doi.org/10.22495/cocv2i4p4

Crisóstomo, V. L., Freire, F. de S., \& Vasconcellos, F. C. de. (2011). Corporate social responsibility, firm value and financial performance in Brazil. Social Responsibility Journal, 7(2), 295-309. https://doi.org/S0076-6879(00)212044 [pii]

Dhani, I. P., \& Utama, A. . G. S. (2017). Pengaruh Pertumbuhan Perusahaan, Struktur Modal, dan Profitabilitas Terhadap Nilai Perusahaan. Jurnal Riset Akuntansi Dan Bisnis Airlangga, 2(1), 135-148.

Elliott, W. B., Jackson, K. E., Peecher, M. E., \& White, B. J. (2014). The unintended effect of Corporate Social Responsibility performance on investors' estimates of fundamental value. Accounting Review, 89(1), 275302. https://doi.org/10.2308/accr-50577

Gray, R., Owen, D., \& Adams, C. (1996). Accounting \& accountability: changes and challenges in corporate social and environmental reporting. Prentice Hall. https://doi.org/10.1111/j.1369-7625.2005.00352.x

Gustian, D. (2017). Pengaruh Pertumbuhan Perusahaan, Keputusan Investasi, Dan Keputusan Pendanaan Terhadap Nilai Perusahaan (Studi Empiris pada Perusahaan Manufaktur yang Terdaftar di Bursa Efek Indonesia 2010-2014). Jurnal Akuntansi., 3(2), 84-100.

Handriyani, A. N., \& Andanyani. (2013). Pengaruh Corporate Social Responsibility Terhadap Nilai Perusahaan Dengan Profitabilitas Sebagai Variabel Moderating. Jurnal Ilmu \& Riset Akuntansi, 2(5).

Hartono, U., Subroto, B., Djumahir, \& Irianto, G. (2013). Firm Characteristics, Corporate Governance and Firm Value. International Journal of Business and Behavioral Sciences, 3(8), 9-18.

Hestinoviana, V., Suhadak, \& Handayani, S. R. (2013). The Influence Of Profitability, Solvability, Asset Growth, And Sales Growth Toward Firm Value (Empirical Study on Mining Companies Which Listed on Indonesia Stock Exchange). Jurnal Administrasi Bisnis, 4(2).

Husted, B. W., \& Allen, D. B. (2007). Strategic Corporate Social Responsibility and Value Creation among Large Firms. Lessons from the Spanish Experience. Long Range Planning, 40(6), 594-610. https://doi.org/10.1016/j.lrp.2007.07.001

Jo, H., \& Harjoto, M. A. (2011). Corporate Governance and Firm Value: The Impact of Corporate Social Responsibility. Journal of Business Ethics, 103(3), 351-383. https://doi.org/10.1007/s10551-011-0869-y 
Kasmir. (2010). Pengantar Manajemen Keuangan. Jakarta: Penamedia Group.

Kesuma, A. (2009). Analisis Faktor yang Mempengaruhi Struktur Modal Serta Pengaruhnya Terhadap Harga Saham Perusahaan Real Estate yang Go Public di Bursa Efek Indonesia. Jurnal Manajemen Dan Kewirausahaan, 11(1), 3845. https://doi.org/10.9744/JMK.11.1.PP. 38-45

Kusumajaya, D. K. O. (2011). Pengaruh Struktur Modal dan Pertumbuhan Perusahaan terhadap Profitabilitas dan Nilai Perusahaan pada Perusahaan Manufaktur di Bursa Efek Indonesia. Universitas Udayana.

Latupono, S. S., \& Andayani. (2015). Pengaruh Corporate Social Responsibility Terhadap Nilai Perusahaan: Good Corporate Governance Variabel Moderating. Jurnal Ilmu \& Riset Akuntansi, 4(8).

McWilliams, A., \& Siegel, D. (2001). Corporate social responsibility: A theory of the firm perspective. Academy of Management Review. https://doi.org/10.5465/AMR.2001.4011987

Meidiawati, K., \& Mildawati, T. (2016). Pengaruh Size , Growth , Profitabilitas , Struktur Modal , Kebijakan Dividen Terhadap Nilai Perusahaan. Jurnal Ilmu Dan Riset Akuntansi, $\quad$ 5(2), 1-16. https://doi.org/10.1021/acs.bioconjchem.7b00016

Nahda, K., \& Harjito, D. A. (2011). Pengaruh Corporate Social Responsibility Terhadap Nilai Perusahaan Dengan Corporate Governance. Siasat Bisnis, 15(1), 1-12.

Puspita, N. S., \& Mahfud, K. (2011). Analisis Pengaruh Struktur Modal, Pertumbuhan Perusahaan, Ukuran Perusahaan, Dan Profitabilitas Terhadap Nilai Perusahaan Pada Perusahaan Manufaktur Yang Terdaftar Di Bursa Efek Indonesia Periode 2007 - 2009. Universitas Diponegoro.

Ramona, S. (2017). Pengaruh Corporate Social Responsibility Terhadap Nilai Perusahaan Dengan Profitabilitas Sebagai Variabel Moderating (Studi Empiris Perusahaan Sektor Pertambangan yang Terdaftar di Bursa Efek Indonesia Periode 2011-2015) Diajukan. Jurnal Fakultas Ekonomi Prodi Akuntansi Universitas Pasir Pengaraian.

Rasyid, A. (2015). Effects of Ownership Structure, Capital Structure, Profitability and Company's Growth Towards Firm Value. International Journal of Business and Management Invention, 4(4), 25-31.

Roberts, R. W. (1992). Determinants of corporate social responsibility disclosure: An application of stakeholder theory. Accounting, Organizations and 
Society, 17(6), 595-612. https://doi.org/10.1016/0361-3682(92)90015-K

Rustiarini, N. I. W. (2010). Pengaruh Corporate Governance pada Hubungan Corporate Social Responsibility dan Nilai Perusahaan. Simposium Nasional Akuntansi XIII, 15(1), 1-24.

Sahla, W. A., \& Aliyah, S. S. R. (2016). Pengungkapan Corporate Social Responsibility Berdasarkan Global Reporting Initiative ( GRI-G4 ) pada Perbankan Indonesia. Jurnal INTEKNA, 16(2), 101-200.

Suastini, N. M., Purbawangsa, I. B. A., \& Rahyuda, H. (2016). Pengaruh Kepemilikan Manajerial dan Pertumbuhan Perusahaan Terhadap Nilai Perusahaan Pada Perusahaan Manufaktur di Bursa Efek Indonesia (Struktur Modal Sebagai Variabel Moderasi). E-Jurnal Ekonomi Dan Bisnis Universitas Udayana, 5(1), 143-172.

Suwardika, I. N. A., \& Mustanda, I. K. (2017). Pengaruh Leverage, Ukuran Perusahaan, Pertumbuhan Perusahaan, dan Profitabilitas Terhadap Nilai Perusahaan Pada Perusahaan Properti. E-Jurnal Manajemen Unud, 6(3), 1248-1277. https://doi.org/10.31093/jraba.v2i1.28

Syardiana, G., Rodoni, A., \& Putri, Z. E. (2015). Pengaruh Investment Opportunity Set, Struktur Modal, Pertumbuhan Perusahaan, dan Return On Asset terhadap Nilai Perusahaan. Akuntabilitas, 8(1), 39-46.

Wijaya, B. I., \& Sedana, I. B. P. S. (2015). Pengaruh Profitabilitas Terhadap Nilai Perusahaan (Kebijakan Dividen dan Kesempatan Investasi Sebagai Variabel Mediasi). E-Jurnal Manajemen Unud, 4(12), 4477-4500. 